\section{Commentary: Eighty is not the new 50: Recognizing risk in the elderly surgical patient}

\author{
Andra E. Duncan, MD, MS, FASE
}

The elderly segment of the US population continues to grow rapidly. In fact, older adults are predicted to outnumber children within the next decade. ${ }^{1}$ As the prevalence of cardiovascular disease increases with age, a growing elderly population will require a greater number of cardiovascular interventions and surgery. Advancements in surgical technique and perioperative care have improved outcomes, although elderly patients remain at greater risk for postoperative mortality and morbidity. ${ }^{2,3}$ Careful patient selection and perioperative decision-making are needed to improve postoperative outcomes and quality of life for the elderly cardiac surgical patient.

In this issue of the Journal, Atladottir and colleagues ${ }^{4}$ provide data and guidance to address patient selection and perioperative decision-making for patients aged 80 years and older. In a cohort of 2342 elderly cardiac surgical patients, the authors examined perioperative risk factors associated with greater 30-day and 1-year postoperative mortality. Although previous reports examined risk factors $^{5,6}$ and reported outcomes in elderly cardiac surgical patients, ${ }^{7}$ this report includes a large cohort of patients with excellent 1-year follow-up. One risk factor, severely impaired preoperative renal function (creatinine clearance $\leq 30 \mathrm{~mL} / \mathrm{min}$ ), was associated with an observed 1 -year mortality greater than $30 \%$ - a nearly 5-fold increase in risk. Additional intraoperative and postoperative variables were also strongly associated with adverse outcomes. For example, cardiopulmonary bypass time greater than $180 \mathrm{mi}-$ nutes was associated with a nearly 6-fold increase in the odds of 1-year mortality. Intraoperative transfusion of greater than 2 units of red blood cells and postoperative

From the Department of Cardiothoracic Anesthesia and Outcomes Research, Cleveland Clinic, Cleveland, Ohio.

Disclosures: Author has nothing to disclose with regard to commercial support.

Received for publication March 17, 2020; revisions received March 17, 2020; accepted for publication March 18, 2020; available ahead of print April 10, 2020.

Address for reprints: Andra E. Duncan, MD, MS, FASE, Department of Cardiothoracic Anesthesia, Cleveland Clinic, 9500 Euclid Ave, J4-328, Cleveland, OH 44195 (E-mail: duncana@ccf.org).

J Thorac Cardiovasc Surg 2021;162:1578-9

$0022-5223 / \$ 36.00$

Copyright (c) 2020 by The American Association for Thoracic Surgery

https://doi.org/10.1016/j.jtcvs.2020.03.099

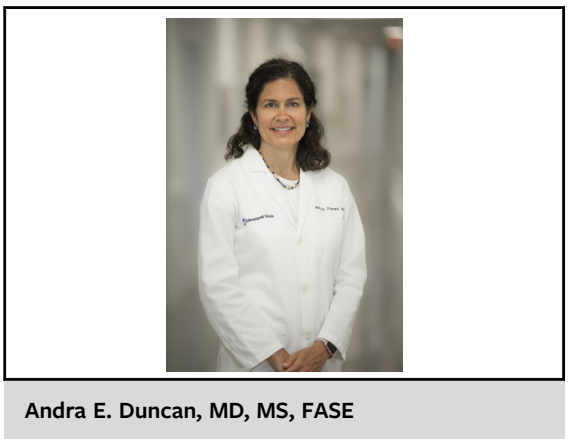

CENTRAL MESSAGE

Identifying risk factors for post-

operative mortality improves

patient selection and periopera-

tive decision-making while

providing realistic expectations

for the elderly cardiac surgical

patient.

factors, including length of intensive care unit stay $>3$ days, were associated with a $4-$ to 6 -fold increase in the odds of 1-year mortality with an observed 1-year mortality of about $30 \%$.

Identification of these risk factors for adverse outcomes is not new. ${ }^{8,9}$ However, this report quantifies risk for 1-year mortality and nicely illustrates the extent that risk is increased in this elderly population. These data provide guidance to help identify patients who are more likely to benefit from surgery. Although many of the reported variables (ie, perioperative blood transfusion, prolonged cardiopulmonary bypass time) are not known preoperatively, evidence is provided to support a decision to perform a less-complicated surgical procedure in an elderly patient - thus reducing exposure to these perioperative risk factors. The quantification of risk in this report provides realistic expectations of potential benefit for elderly patients who present for cardiac surgery.

\section{References}

1. US Census Bureau website. Available at: https://www.census.gov/library/ visualizations/2018/comm/historic-first.html. Accessed March 17, 2019.

2. Johnson WM, Smith JM, Woods SE, Hendy MP, Hiratzka LF. Cardiac surgery in octogenarians: does age alone influence outcomes? Arch Surg. 2005;140:1089-93.

3. Habib AM, Hussain A, Jarvis M, Cowen ME, Chaudhry MA, Loubani M, et al. Changing clinical profiles and in-hospital outcomes of octogenarians undergoing cardiac surgery over 18 years: a single-centre experience. Interact Cardiovasc Thorac Surg. 2019;28:602-6.

4. Atladottir HO, Modrau IS, Jakobsen C-J, Torp-Pedersen CT, Gissel MS, Nielsen DV. Impact of perioperative course during cardiac surgery on outcomes in patients 80 years and older. J Thorac Cardiovasc Surg. 2021;162:1568-77. 
5. Shavit L, Lifschitz M, Slotki I, Oren A, Tauber R, Bitran D, et al. Preoperative renal dysfunction and clinical outcomes of cardiac surgery in octogenarians. Exp Gerontol. 2013;48:364-70.

6. Scandroglio AM, Finco G, Pieri M, Ascari R, Calabrò MG, Taddeo D, et al. Cardiac surgery in 260 octogenarians: a case series. BMC Anesthesiol. 2015; $15: 15$.

7. Arora RC, Manji RA, Singal RK, Hiebert B, Menkis AH. Outcomes of octogenarians discharged from the hospital after prolonged intensive care unit length of stay after cardiac surgery. J Thorac Cardiovasc Surg. 2017;154: 1668-78.e2.

8. Thakar CV, Worley S, Arrigain S, Yared JP, Paganini EP. Influence of renal dysfunction on mortality after cardiac surgery: modifying effect of preoperative renal function. Kidney Int. 2005;67:1112-9.

9. Koch CG, Li L, Duncan AI, Mihaljevic T, Loop FD, Starr NJ, et al. Transfusion in coronary artery bypass grafting is associated with reduced long-term survival. Ann Thorac Surg. 2006;81:1650-7.
See Article page 1568.

\section{Commentary: Age is just a number?}

Richa Dhawan, MD, MPH, and Mark A. Chaney, MD

The life expectancy in the United States is 78.6 years per Centers for Disease Control and Prevention reports. ${ }^{1}$ It is estimated that by 2050, 19 million Americans will be 85 and older and 1 million will be 100 years and older. ${ }^{2}$ Although an amazing achievement of medical advancement and technology, it is an immense challenge to health care delivery. The majority of these individuals will be living with chronic health conditions requiring medical or surgical care. Often this vulnerable population is excluded from clinical trials, yet the health care community needs vigorous scientific research to understand this group's unique medical needs. In this light, the Journal presents an important study by Atladottir and colleagues. This retrospective study included 2342 patients older than the age of 80 years undergoing open-heart surgery. ${ }^{3}$ The authors performed a logistic regression analysis to determine preoperative, intraoperative, and postoperative risk factors associated with an increase in morbidity and mortality. They found that severe renal impairment (glomerular filtration rate $<40 \mathrm{~mL} / \mathrm{min}$ ) and prolonged cardiopulmonary bypass time (>180 minutes) were associated with greater than $50 \%$ mortality at 1 year. Postoperative intensive care length

\footnotetext{
From the Department of Anesthesia and Critical Care, University of Chicago Medical Center, Chicago, Ill.

Disclosures: Authors have nothing to disclose with regard to commercial support.

Received for publication March 19, 2020; revisions received March 19, 2020; accepted for publication March 20, 2020; available ahead of print April 6, 2020

Address for reprints: Richa Dhawan, MD MPH, Department of Anesthesia and Critical Care, University of Chicago Medical Center, 5841 South Maryland Ave, MC 4028, Chicago, IL 60637 (E-mail: rdhawan@dacc.uchicago.edu).

J Thorac Cardiovasc Surg 2021;162:1579-80

$0022-5223 / \$ 36.00$

Copyright (c) 2020 by The American Association for Thoracic Surgery

https://doi.org/10.1016/j.jtcvs.2020.03.078
}

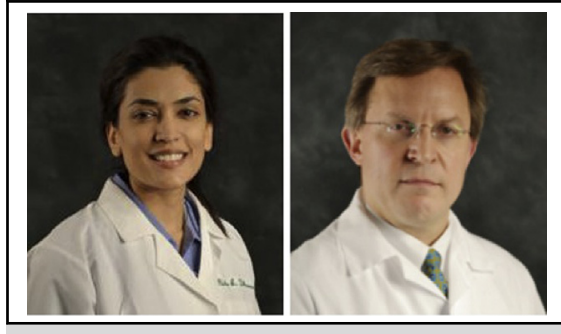

Richa Dhawan, MD, MPH, and Mark A. Chaney, MD

CENTRAL MESSAGE

Octogenarians are a complex patient population. Specific risk factors that predispose them to increased morbidity and mortality after cardiac surgery need to be further elucidated.

of stay greater than 3 days and mechanical ventilation greater than 2 days were also associated with increased mortality within 1 year.

Although the findings of this study are not surprising, they pose vital questions about health care objectives for the very elderly. What is the best care for these patients? Is $50 \%$ mortality acceptable? The study lacks data on postoperative quality of life and cognitive function. Are patients able to return to their normal lives after surgery? As clinicians we lack a comprehensive understanding of the risks and benefits of medical/surgical treatment for the elderly. Part of the puzzle is that chronological age is not necessarily equivalent to biological age. Some octogenarians live independent, active lives, whereas others need assisted living due to a decline in physiological functional capacity. In the last decade, the concept of frailty, rather than age or disease, as immerged as a valuable measure of preoperative risk 